\title{
Seasonal Changes In Lipid Content, In The Adductor Muscles Of Cerebralectomied Freshwater Bivalve Mussel Lamellidens Corrianus.
}

\author{
Sangeeta . B. Dongre And *D.L.Sonwane \\ Department of Zoology Milind College Of Science, Nagsenvana Aurangabad.431001. \\ * Department of Zoology Dr. Babasaheb Ambedkar Marathwada University Aurangabad. 431001.
}

\begin{abstract}
Lipids play a nutritional physiological role by providing an efficient source of energy and essential fatty acids. As the freshwater bivalves are the filter feeder the role of adductor muscles are very efficient. A seasonal change in endogenous and exogenous factors in freshwater bivalves requires more energy and is control by various ganglion such as cerebral, visceral and pedal, hence the present investigation was undertaken to study the impact of cerebral ganglia on lipid content in adductor muscles of freshwater mussel Lamellidens Corrianus.
\end{abstract}

Key Words: Lipids, Season, cerebralectomy and Lamellidens corrianus.

\section{Introduction:}

Bivalves have been exploited worldwide for food, ornamentation and pearls throughout human history. Freshwater mussels are distributed worldwide in lotic and lentic habitats. As filter feeders, freshwater mussels are ecologically important; they control seston, recycle nutrients and provide a tropic link between primary producer and predators, (Lewandowski, et al., 1991).

Lipids are major sources of metabolic energy and essential compounds for the formation of cell and tissue membranes and they are important in the process of egg production. They also provide energy for growth during conditions of limited food supply, when carbohydrate levels are low while lipid composition and metabolism have been extensively studied in marine mollusks, a few investigations have been carried the fatty acid composition of freshwater species. A detailed account of fatty acids of freshwater prosobranch mollusks from Russia, USA and India has been published. The lipid composition of the mollusks can be affected by external (exogenous) factors, such as fluctuations in the environmental conditions (temperature and food availability), or by internal (endogenous) factors, such as metabolic and physiological activities. The lipid composition of freshwater gastropods from India has been studied to some extent. The primary goals of this study were to characterize the lipid composition in the anterior adductor muscles of the freshwater mussel Lamellidens corrianus, collected from Nandrabad pond near Aurangabad. Lipid composition and metabolism have been extensively studied in marine bivalves; a few investigations have been done on freshwater forms (Pollero et al., 1981, 1983; Dembitsky et al., 1992,1993; Ekin et al., 2008) and even less on organs and tissues of freshwater species. As mentioned before, there were not much more studies on fatty acid composition of freshwater bivalve tissues. Among the known studies, only some of the freshwater bivalves ,Carunculina texasensis (Hagar and Dietz, 1986),Diplodom patagonicus (Pollero et al., 1981), Ligumiasubrostrata (Dietz and Graves, 1981), Diplodondelodontus (Pollero et al., 1983), Dreissenapolymorpha and Unio sp. (Dembitsky et al., 1992) and Dreissena siouffi (Ekin et al., 2008) have been reported, but very little attention is given on the role of cerebral ganglia in regulating the lipid metabolism hence the present investigation has been undertaken to study the impact of removal of cerebral ganglia unilaterally and bilaterally in lipid content in adductor muscles in freshwater bivalve mussel Lamellidens Corrianus during different season.

\section{Material Method:}

The freshwater bivalve molluscs, Lamellidens corrianus inhabits in the Nandrabad pond situated in Khultabad taluka 19km away from Aurangabad. During summer, monsoon, post-monsoon and winter season the collection of 15 individuals of the shell length $95-110 \mathrm{~mm}$ were selected and were acclimatized to laboratory condition for $24 \mathrm{~h}$. Surgical operations were performed so as to remove cerebral ganglia unilaterally and bilaterally within 30 seconds after lapse of 2 to 3 hours in the laboratory condition. The animals were divided into 3 groups non- operated served as control and other two were experimental. In each group 5 animals were selected and after lapse of 7 days the animals were sacrificed and the adductor muscle, were dissected and dried in the oven to prepare the powder for estimation of Lipids using standard method Vanillin reagent method of Barnes et al. [1973]. The value of estimate was subjected to statistical analysis. 


\section{ESTIMATION OF LIPID:}

The total Lipid was estimated by the vanillin reagent method of Barnes et al. [1973].

The quantitative determination of lipid by sulpho-phosphovanillin method depends on the reaction of lipids (extracted from the sample using chloroform: methanol) with sulphuric acid, phosphoric acid and vanillin to give a red colour complex.

\section{Reagents:}

Chloroform: Methanol [2:1 v/v]

Conc. Sulphuric acid,

Orthophosphuric acid.

Vanillin Reagent: 2 gm vanillin in $200 \mathrm{ml} \mathrm{H} 2 \mathrm{O}$. Add $800 \mathrm{ml}$ Orthophosphuric acid. Keep in dark bottle for 15 to 20 days before use.

\section{Procedure:}

$100 \mathrm{mg}$ tissue was homogenized by adding $10 \mathrm{ml}$ of chloroform: methanol (2:1) mixture. The homogenate was filtered and $1 \mathrm{ml}$ of this filtrate was kept at room temperature in laboratory at $37^{\circ} \mathrm{C}$ for 2 days. $1 \mathrm{ml}$ of concentrated sulphuric acid was added to dry mixture and kept in boiling water bath for exactly 10 minutes, followed by rapid cooling under tap water. $0.2 \mathrm{ml}$ of this solution was taken and $5 \mathrm{ml}$ vanillin reagent was added and kept aside for 30 minutes at room temperature $\left(37^{\circ} \mathrm{C}\right)$. The optical density was read at $530 \mathrm{~nm}$ using UV-VIS Spectrophotometer.

Cholesterol was used as a standard. Lipid content was calculated with the help of standard graph and expressed as $\mathrm{mg} / 100 \mathrm{mg}$ wet tissue.

\section{Results And Discussion:}

Lipid contents were determined in dry samples of anterior adductor muscles, in each individual. The results of the experiments were shown in Table. 1.and Fig,1. The physico-chemical parameters of the water used in the experiments during different season were also studied temperature was in between $33^{\circ} \mathrm{C}$ to $22^{0} \mathrm{C} ; \mathrm{pH} 7.4$ to 7.6 ; hardness 240 to $100 \mathrm{mg} / \mathrm{L}$ and oxygen content 4.40 to $9.67 \mathrm{mg} / \mathrm{L} / \mathrm{h}$. Impacts of cerebralectomy were studied to determine the biochemical lipid content in adductor muscle of freshwater bivalve mussel, Lamellidens corrianus. The mussel anterior adductor muscle were analyzed to observe the effect of cerebralectomy unilaterally and bilaterally respectively. The data were exposed to various statically analysis. Student ' $t$ ' test was used to find out significance. The level of significance was used in the present study $(\mathrm{p}<0.001, \mathrm{p}<0.01$ and $\mathrm{p}<0.05)$.

Lipids: In the anterior adductor muscles of control mussel, the Lipid level was observed in summer was showed a significant increase $3.57 \pm 0.11 \mathrm{mg}$ as compared to experimental mussels. In unilateral group mussel the content was $3.08 \pm 0.04 \mathrm{mg}$ and in bilaterally cerebralectomized mussel the anterior adductor muscle content $3.54 \pm 0.09 \mathrm{mg}$ was respectively.

In Monsoon the $3.08 \pm 0.04 \mathrm{mg}$ content in control mussel was shown an decrease level in lipids $1.19 \pm$ $0.13 \mathrm{mg}$ as compared to summer season. In experimental mussel the Lipids level showed a significant $(\mathrm{p}<0.001)$ decrease $1.19 \pm 0.04 \mathrm{mg}$ in unilaterally cerebralectomized mussel by $35.60 \%$ a significant $(\mathrm{p}<0.001)$ decreased in bilaterally cerebralectomized mussel. $0.87 \pm 0.04 \mathrm{mg}$, by $23.35 \%$.

In post monsoon the Lipids content was again showed a $5.09 \pm 0.02 \mathrm{mg}$ significant decrease by $20.22 \%$ in control mussel. In experimental mussel the Lipids content was significantly increased in unilaterally cerebralectomized mussels $12.03 \pm 0.10$ and $4.14 \pm 0.09$ by $30.26 \%$ and $76.23 \%(p<0.001)$. Where as the lipids content was maximum in post-monsoon season in control mussel as compared to other seasons.

In winter season the lipid content in control group was $1.17 \pm 0.09,(29.35 \%)$ and in experimental group mussel were $0.83 \pm 0.04(69.86 \%)$ and $1.16 \pm 0.008(98.06 \%)$ a significant increase was observed as to control animals.

Lipid is an important dietary constituent, serve as reserve energy when food supply is scanty. In stressful environmental conditions, after glycogen lipid is use as energy source (Shigmates and Takeshita, 1959). In the present study the lipid content decline in winter indicate that at the time of fully maturity of gonads the other biochemical content increased and lipid content lower and increased in post- monsoon due to the ripening and matured released of gametes.

Lipid composition and storage strategy in molluscs, particularly of bivalves and gastropods have been studied since lipids constitute a major fraction of molluscan tissues (Voogt, 1983). Almost concern the entire organism and only a few reports on the tissue distribution of fatty acids are available (Hagar and Dietz, 1986; Wenne and Polak, 1989)

Nutritional state can vary both seasonally and annually .Freshwater and marine water bivalve's display marked seasonal variations in weight and biochemical content of the soft tissue. (Zandee et al., 1980, Williams and McMahon 1989),Among the known studies, only some of the freshwater bivalves, Carunculina texasensis 
(Hagar and Dietz, 1986),Diplodom patagonicus (Pollero et al., 1981), Ligumiasubrostrata (Dietz and Graves, 1981Diplodondelodontus (Pollero et al., 1983), Dreissenapolymorpha and Unio sp. (Dembitsky et al., 1992) and Dreissena siouffi (Ekin et al., 2008) have been reported, but very few literature is available on impact of cerebralectomy, hence the study was undertaken, thus it might be concluded that the impact of removal of cerebral ganglia unilaterally and bilaterally has a inhibitory effect in lipid content metabolism.

\section{Acknowledgment:}

The author is thankful to the Principal, Vice- Principal and all teaching faculty and friends for their constant support and guidance.

Table.1 Lipids content in Anterior Adductor Muscles of freshwater bivalve mussel, Lamellidens corrianus, during different Season.

\begin{tabular}{|c|c|c|c|}
\hline SEASONS & $\begin{array}{l}\text { CONTROL } \\
\text { GROUP MUSSEL }\end{array}$ & $\begin{array}{l}\text { UNILATERALLY } \\
\text { CEREBRALECTOMIZED } \\
\text { GROUP MUSSEL }\end{array}$ & $\begin{array}{l}\text { BILATERALLY } \\
\text { CEREBRALECTOMIZED } \\
\text { MUSSEL. }\end{array}$ \\
\hline SUMMER & $\begin{array}{l}3.57 \pm 0.11 \\
(82.80 \%) * *\end{array}$ & $\begin{array}{l}3.08 \pm 0.04 \\
(82.90)^{* * *}\end{array}$ & $\begin{array}{l}3.54 \pm 0.09 \\
(95.67) * *\end{array}$ \\
\hline MONSOON & $\begin{array}{l}3.08 \pm 0.04 \\
(55.50 \%)^{* * *}\end{array}$ & $\begin{array}{l}1.19 \pm 0.13 \\
(35.60 \%) * *\end{array}$ & $\begin{array}{l}0.87 \pm 0.04 \\
(23.35 \%) * * *\end{array}$ \\
\hline POST-MONSOON & $\begin{array}{l}5.09 \pm 0.02 \\
(17.99)^{* * *}\end{array}$ & $\begin{array}{l}12.03 \pm 0.10 \\
(30.26 \%) * * *\end{array}$ & $\begin{array}{l}4.14 \pm 0.09 \\
(76.23 \%) * * *\end{array}$ \\
\hline WINTER & $\begin{array}{l}1.17 \pm 0.09 \\
(29.35 \%) * * *\end{array}$ & $\begin{array}{l}0.83 \pm 0.04 \\
(69.86 \%)\end{array}$ & $\begin{array}{l}1.16 \pm 0.008 \\
(98.06 \%)\end{array}$ \\
\hline
\end{tabular}

$* \mathbf{p}<0.05 . * * \mathbf{p}, 0.01 * * * \mathbf{p}<0.1$.

Fig.1 Seasonal Changes in Lipids content in anterior adductor muscles, in $L$. corrianus

\section{Seasonal variation in Lipid content in anterior adductor muscles, in L. corrianus.}

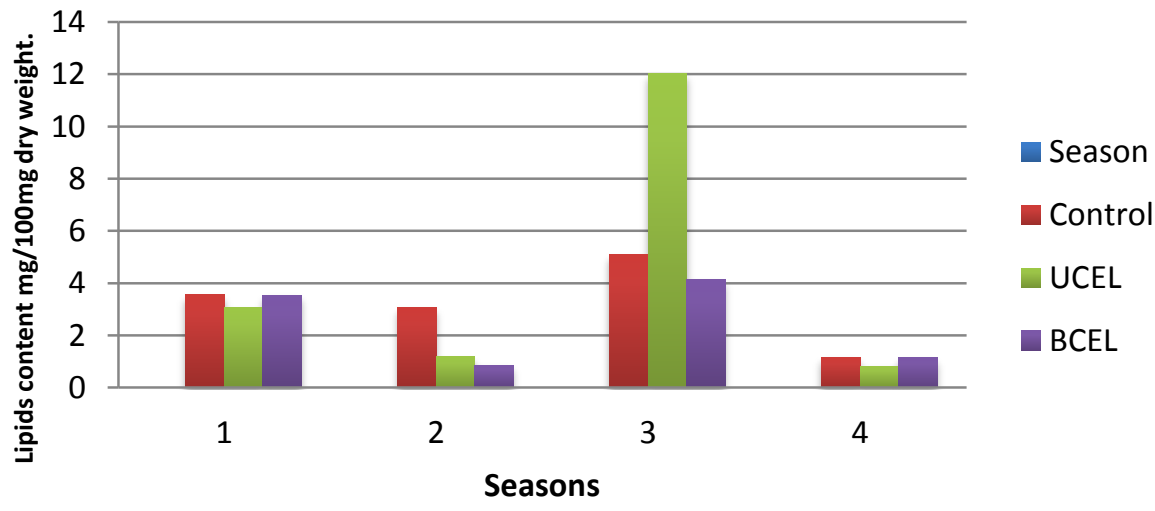

UCEL- Unilateral cerebralectomized mussel : BCEL- Billaterally crebrlectomized mussel.

\section{Reference:}

[1]. Alkanani, T., Parrish, C.C., Thompson, R.J. and McKenzie,C.H. 2007. Role of fatty acids in cultured mussels, Mytilus edulis, grown in Notre Dame Bay,Newfoundland. Journal of Experimental Marine Biology and Ecology, 348: 33-45.

[2]. Barnes and Balakstock, 1973: Estimation of lipids in the marine animal tissues.; detailed investigation of sulphophosphovanilline method for total lipids. J. Expt. Mar. Biol. Ecol. 12(1) 103-108.

[3]. Beninger PG, Lucas A 1984. Seasonal variations in condition,reproductive activity and gross biochemical composition of two species of adult clam reared in a common habitat: Tapes

[4]. decussatus L. (Jeff reys) and Tapes philippinarum (Adams and Reeve). J Exp Mar Biol Ecol 79: 19-37,

[5]. Dembitsky VM, Kashin AG, Stefanow K. 1992. Comparative investigation of phospholipids and fatty acids of freshwater molluscs from Volga River Basin. Comp. Biochem Physiol.102B: 193-198,

[6]. Dembitsky VM, Rezanka T, Kashin AG. 1993a. Fatty acid and phospholipids composition of freshwater molluscs Anadonta piscinalis and Limnaea fragilis from the River Volga. Comp

[7]. Biochem Physiol 105B, 3: 597-601,

[8]. Dembitsky VM, Rezanka T, Kashin AG. 1993b. Comparative study of the endemic freshwater fauna of Lake Baikal-I. Phospholipids and fatty acid composition of two mollusc species, Baicalia oviformis and Benedictia baicalensis. Comp. Biochem. Physiol

[9]. 106B: 819-823. 
[10]. Ekin İ, Başhan M, Şeşen R. 2008. Fatty acid composition of Dreissena siouffi (Bivalvia: Dreissenidae) collected from the Fırat River. Science and Eng. J of Firat Univ 20 (2): 243-50..

[11]. Gabbott PA. Developmental and seasonal metabolic activitiesin marine molluscs. In: Hochacka PW. ed.. The Mollusca. New York: Academic Press: 1983: pp. 165-217.

[12]. Hagar AF, Dietz TH. 1986. Seasonal changes in the lipid composition of gill tissue from the freshwater mussel Carunculina texasensis. Physiol Zool 59 (4): 419-28

[13]. Lewandowski, K. \& A. Stanczykowska. 1975. The occurrence and role of bivalves of the family Unionidae in Mikolajskie Lake. Ekologia Polska 23: 317-334

[14]. Pollero R.J, Irazu C.E, Brenner R.R. 1983.Eff ect of sexual stage on lipids and fatty acids of Diplodon delodontus. Comp .Biochem. Physiol 76B: 927-931,

[15]. Misra, S., Ghosh, K.M., Choudhury, A., Dutta, K.A., Pal, K.P. and Ghosh, A. 1985. Fatty acids from Macoma sp. of bivalve mollusc. Journal of the Science of Food and Agriculture, 36: 1193-1196.

[16]. Pazos JA, Ruiz C, Martin GO, Abad M, Sanchez LJ. (1996). Seasonal variation of the lipid content and fatty acid composition of Crassostrea gigas cultured in El Grove, Galicia, N.W. SPAIN. Comp Biochem Physiol 114B: 171-79.

[17]. Pazos JA, Sanchez LJ, Roman G, Perez-Parelle ML, Abad M.2003).Seasonal changes in lipid classes and fatty acids composition in digestive gland of Pecten maximus. Comp Biochem

[18]. Physiol 134B: 367-80.

[19]. Pollero, J. R., M. E. Re \& R. Brenner. 1979. Seasonal changes of the lipids of the mollusc Chlamys tehuelcha. Comp. Biochem. Physiol. 64A:257-263.

[20]. Pollero, J. R., C. Irazu \& R. Brenner. 1983. Effect of sexual stages on lipids and fatty acids of Diplodon delodontus. Comp. Biochem. Physiol. 76B: 927-931

[21]. Pollero, R.J., Brenner, R.R. and Gros, G.E. 1981. Seasonal changes in lipid and fatty acid composition of the freshwater mollusc Diplodom patagonicus. Lipids, 16(2): 109-113

[22]. Pazos, A. J.; Ruiz, C.; Garcia-Martin, O.; Abad, M.;Sanchez, J. L. 1996: Seasonal variations of the lipid content and fatty acid composition of Crassostrea gigas cultured in El Grove, Galicia,

[23]. N.W. Spain. Comparative Biochemistry and Physiology 114B: 171-179.

[24]. Trider, D.J. and Castell, J.D. ,1980. Influence of neutral lipid on seasonal variation of total lipids in oysters Crassostrea virginica. Proceeding of the National Shellfisheries Association,70: 112-118.

[25]. Voogt, P.A. 1983. Lipids: Their distribution and metabolism in the Mollusca. In: P.W. Hochachke (Ed.), Metabolic Biochemistry and Molecular Biomechanics Academic Press, New York: 329-370.

[26]. Watanabe, T. and Ackman, R.G. 1974. Lipids and fatty acids of the American (Crassostrea virginica) and European flat (Ostrea edulis) oysters from a common habitat and after one feeding with Dicrateria inornata or Isochrysis galbana. Journal of the Fisheries Research Board of Canada, 31: 403-409.

[27]. Wenne R, Polak L. (1989) Lipid composition and storage in the tissues of the Macoma balthica. Biochem. Syst. Ecol., 17: 58387.out on freshwater forms and even less on seasonal variations in 